\title{
Recent Advances in Biomass-Based Waste Materials for the Removal of Chromium (VI) from Wastewater: A Review
}

Rajan Rai ${ }^{1}$, Dirgha Raj Karki ${ }^{2}$, Krishna Prasad Bhattarai ${ }^{1}$, Bishnu Pahari $^{1}$, Nabina Shrestha ${ }^{1}$, Sangita Adhikari', Surendra Kumar Gautam ${ }^{*}$, Bhoj Raj Poudel ${ }^{1,2^{*}}$

${ }^{1}$ Department of Chemistry, Tri-Chandra Multiple Campus, Tribhuvan University, Kathmandu, Nepal

${ }^{2}$ Central Department of Chemistry, Tribhuvan University, Kathmandu, Nepal

*E-mail: sgautam2055@yahoo.com,chembrpoudel@gmail.com

(Received:14 April 2021, Received in revised form: 22 April, Accepted: 27 June 2021, Available Online)

\section{Highlights}

- $\quad \mathrm{Cr}(\mathrm{VI})$ is more toxic because of its carcinogenic effects in humans.

- Adsorption is a very effective and helpful method for the removal of $\mathrm{Cr}(\mathrm{VI})$.

- $\quad$ The modified adsorbents are found more effective in comparison to unmodified adsorbents.

- $\quad$ Biomass-based waste materials could be good alternatives for $\mathrm{Cr}(\mathrm{VI})$ removal.

\begin{abstract}
Hexavalent chromium (Cr(VI)) is a critical pollutant with high toxicity, even at trace concentrations. Cr(VI) is possibly carcinogenic and mutagenic and can produce serious health issues. Hence, it is necessary to remove Cr(VI) from the water before releasing it into the environment. Currently, numerous removal techniques were used. Adsorption is the best method compared to others because it is simple, cheap, highly efficient, and can be used in water having trace concentrations of contaminants. Biomass-based waste materials (BMWs) are found as far better adsorbents than commercially and other available adsorbents. In this study, the existing Cr(VI) removal techniques are reviewed and, a broad range of current research studies of Cr(VI) removal from water by using BMWs are evaluated. This review can be helpful to develop a more efficient, cheap, reliable, and environmentally benign bio-adsorbent. It is obvious after the literature review given herein that BMWs exhibited potential adsorbents for the removal of Cr(VI). Also, the chemically modified adsorbents exhibited a higher adsorption capacity than unmodified adsorbents.
\end{abstract}

Keywords: $C r(V I)$, Water, BMWs, Adsorbents, Adsorption

\section{Introduction}

The water quality is affected mainly by organic contaminants and heavy metals. Heavy metals in water cause widespread harm to human health. The metallic elements having a density greater than $5.0 \mathrm{~g} / \mathrm{cm}^{3}$ are called heavy metals. The most common heavy metals are $\mathrm{Cd}\left(8.65 \mathrm{~g} / \mathrm{cm}^{3}\right), \mathrm{Cr}\left(7.14 \mathrm{~g} / \mathrm{cm}^{3}\right), \mathrm{Co}(8.90 \mathrm{~g} / \mathrm{cm} 3), \mathrm{Cu}\left(8.95 \mathrm{~g} / \mathrm{cm}^{3}\right), \mathrm{Pb}\left(11.34 \mathrm{~g} / \mathrm{cm}^{3}\right)$, and $\mathrm{Hg}\left(13.53 \mathrm{~g} / \mathrm{cm}^{3}\right)$. Among the toxic heavy metal ions, chromium has a significant impact on the aquatic environment. Chromium, an element having trivalent $[\mathrm{Cr}(\mathrm{III})]$ and hexavalent $[\mathrm{Cr}(\mathrm{VI})]$ as the most stable species. Hexavalent species is usually found in oxyanion as chromate $\left(\mathrm{CrO}_{4}^{2-}\right)$ or dichromate $\left(\mathrm{Cr}_{2} \mathrm{O}_{7}{ }^{2-}\right)$. Trivalent chromium is an essential element for living organisms, while $\mathrm{Cr}(\mathrm{VI})$ is more hazardous due to its carcinogenic effects [1]. The $\mathrm{Cr}(\mathrm{VI})$ is soluble in the aquatic environment of a wide pH range. It is considered the $16^{\text {th }}$ most hazardous pollutant due to its carcinogenic and teratogenic properties [2,3]. Heavy metals including chromium are more potent to toxicity than other organic pollutants due to their non-biodegradable nature [4]. Chromium enters

${ }^{*}$ Corresponding author 
into the aquatic environment through natural sources such as geochemical activity, rock and soil weathering, and anthropogenic sources, including various industrial activities such as tanneries, electroplating, textile processing, alloying, wood preservative, dying, pesticides, and fertilizer production. The most significant release of $\mathrm{Cr}(\mathrm{VI})$ occurring from industrial sources. Naturally, it occurs as crocoite $\left(\mathrm{PbCrO}_{4}\right)$, chrome ochre $\left(\mathrm{Cr}_{2} \mathrm{O}_{3}\right)$, and ferric chromite $\left(\mathrm{FeCr}_{2} \mathrm{O}_{4}\right)$ deposits [5].

Chromium as a metal is biologically inert and does not produce toxic effects in humans. $\mathrm{Cr}$ (III) and $\mathrm{Cr}(\mathrm{VI})$ have different toxicity, mobility, and bioavailability. $\mathrm{Cr}(\mathrm{III})$ is an essential element needed for normal carbohydrate and lipid metabolism in humans. Its deficiency can cause slow removal of sugar from the blood. $\mathrm{Cr}$ (III) and insulin together balance the glucose level in the blood. Hence, it utilizes as a dietary supplement, usually as chromium (III) chloride, chromium (III) polynicotinate, or chromium(III) D-phenylalanine [6]. However, in an excess amount or long-term exposure, it is toxic. $\mathrm{Cr}(\mathrm{VI})$ is much more lethal than $\mathrm{Cr}$ (III) because $\mathrm{Cr}$ (VI) compounds are usually highly soluble, mobile, and bioavailable than $\mathrm{Cr}(\mathrm{III})$ compounds [7]. Even trace level concentrations of $\mathrm{Cr}(\mathrm{VI})$ in drinking water can endanger human health. Compounds of $\mathrm{Cr}(\mathrm{VI})$ are potent oxidants. The toxicological impact of $\mathrm{Cr}(\mathrm{VI})$ arises from the possibility of free diffusion through cell membranes. In the cell, it oxidizes biomolecules and forms free radicals during the reduction of $\mathrm{Cr}(\mathrm{VI})$ to $\mathrm{Cr}(\mathrm{III})$. Thus formed $\mathrm{Cr}(\mathrm{III})$ inside a cell in a significant amount may cause other adverse effects because of its high affinity to bind various organic compounds that inhibit some metalloenzyme systems [8,9]. $\mathrm{Cr}(\mathrm{VI})$ affects physiology, concentrating in the food chain, causes several disorders in human health such as vomiting, bleeding, disturbances, and ulcer in the stomach, kidney, and liver damages, skin rash, weakened immune system and can even lead to sudden death[10,11]. Based on its acute lethal effects on human health, WHO and USEPA promulgated the maximal contamination limit for $\mathrm{Cr}(\mathrm{VI})$ in drinking water not to exceed $0.05 \mathrm{mg} / \mathrm{L}$ and in industrial effluents is $0.25 \mathrm{mg} / \mathrm{L}[11,12]$. The necessity of its removal from the natural environment rises due to its high desolation rate in the wide $\mathrm{pH}$ range of the aqueous phase, non-biodegradable, and obviously due to its toxic nature.

Various methods, such as electro-dialysis, membrane technology, redox reaction followed by precipitation, ion exchange, and adsorption are applied to eliminate(VI) from the aquatic environment $[13,14]$. Requirements for the high energy and expensive instruments, lacking metal removal completion, toxic waste sludge, and disposals, etc., are the reasons which limit the use of most of the options mentioned above [15-18]. The adsorptive method of removal is the most widely used method for the removal of heavy metal pollutants, including $\mathrm{Cr}(\mathrm{VI})$, from the wastewater due to the availability of cheaper materials for the production of low-cost adsorbents [19,20]. Trace concentrations of the metals can even remove by adsorption, which proves this method more beneficial than conventional methods. Despite the usefulness of the adsorbents, they have some disadvantages like low adsorption capacities or long adsorption equilibrium times [21,22]. Therefore, it is crucial to pursuit for novel effective adsorbents. This review focuses on the comparative study of the use of readily available agricultural byproducts as effective adsorbents for removing $\mathrm{Cr}(\mathrm{VI})$ from the aquatic environment.

Recently, several review papers on removing $\mathrm{Cr}(\mathrm{VI})$ from water and wastewaters by adsorption process have been published [23-25]. Most of the reviews focused only one specific type of adsorbents such as carbon nanotubes[26], activated carbon derived from biomass [27], carbonaceous nanomaterials [28],microporous polymers [29], silica-based materials [30], chitosanbased nanocomposite [31], magnetic iron oxides [32], nanoparticle-based adsorbent [33,34], polyaniline-based materials [35], metal-organic framework (MOF)derivatives and their composites [36], and natural minerals [37]. This study offers a significant and thorough review on removing $\mathrm{Cr}(\mathrm{VI})$ from water by using biomass-based waste materials (BMWs) as adsorbents, especially those that have emerged in recent years. This review aims to pursue the adsorbents that are less expensive and to examine their efficacy for removing $\mathrm{Cr}(\mathrm{VI})$ ions from contaminated water.

\section{Chromium (VI) Removal Method}

Several methods are used to remove $\mathrm{Cr}(\mathrm{VI})$, such as ion exchange, chemical precipitation, coagulation, membrane separation, electro-coagulation, reverse osmosis, etc. Due to their high cost and minimal practicability, these processes of removing $\mathrm{Cr}(\mathrm{VI})$ are not applicable. Instead, the adsorption techniques, due to their low cost and high efficiency, are most used though searching for the most efficient adsorbent is still on.

\section{Ion exchange method}

It is the physio-chemical process used for the last few decades based upon the exchange of cation with the metal ion in wastewater. This process involves a reversible exchange of ions between solid and liquid phases, which has received significant 
attention for removing $\mathrm{Cr}(\mathrm{VI})$. Having inexpensive nature and capability of selective metal removal, natural zeolites are used as mediums for ion exchange reactions. In most cases, synthetic ion exchange resins are used. Effect of $\mathrm{pH}$, variation of the solution, expensive synthetic resins, and non-usability on a large scale are the disadvantages of this process [38,39]. Various ion exchange resins such as synthetic Dowex 2-X4 ion exchange resin [40], Ambersep 132 [41], Amberlite XAD-4 (MAX-4) [42], Diaion CR11, and Amberlite IRC86 [43] were studied for $\mathrm{Cr}(\mathrm{VI})$ removal from aqueous solutions.

\section{Chemical precipitation method}

This process is an easy, inexpensive, commonly used one. Chemical reagents like lime, alum, and limestone reacted with the metal ion to form the precipitation, which was later filtered. The requirement of large amounts of reagents, high cost for the disposal of remaining sludge are the disadvantages of this process [44,45].

\section{Coagulation}

In this process, coagulates such as ferric and aluminium chloride form the colloids with the metal ion. The removal in this process is determined by the $\mathrm{pH}$ of the solution, initial metal ion concentration, and concentration of coagulant used. Although used on a larger scale, the expensive coagulants and problems in the sludge disposal are the disadvantages of this process $[46,47]$.

\section{Electrodialysis method}

It is a membrane separation technique to transport ions aided under electrical potential across the membranes $[48,49]$. Based on the methods and the size of the metal ion present, different types of membranes are used to remove the metal ion. Although having advantages like the use of fewer amounts of chemicals and the formation of less amount of sludge, the high maintenance, and operational cost are its drawbacks [50].

\section{Reverse osmosis}

It was a promising membrane technology used to remove the $\mathrm{Cr}(\mathrm{VI})$ by using the semi-permeable membrane [51]. In this process, pressure is applied in the concentrated part followed by the movement of water to a more dilute part, and metal ions are washed away with water. High operational and maintenance expenses and the requirement for increased power for the pressure are the drawbacks of this process [52].

\section{Adsorption process}

This process involves the accumulation of metal ions or adsorbate on the surface of the adsorbent, creating a layer. This process is extensively used because of its low cost and high efficiency. It has some disadvantages too, such as: in some cases, involvement of increased prices to prepare the suitable adsorbent, chemical regeneration, and loss during this process [53,54]. Because of the high price, low efficiency, use of excessive chemicals, production of toxic and non-eco-friendly sludge, and disposal of the sludge, the use of conventional methods of removal of $\mathrm{Cr}(\mathrm{VI})$ is limited. Preferentially, being simple, affordable, highly productive and efficient, and low cost, the adsorption method of removing $\mathrm{Cr}(\mathrm{VI})$ metal ions is mainly used [54]. Aside from the adsorption process, the search for a suitable adsorbent is essential too. For the selection of a suitable adsorbent, the cost factor is the important one. With the cost factor, the adsorbents should be widely available and should require little processing. Biomass-based waste materials (BMWs) present a better and inexpensive alternative for adsorbents [55].

\section{Adsorbents for Removing of Chromium (VI)}

Having high surface area and various functional groups, commercially available adsorbents like graphene, activated carbon, and carbon nanotube act as efficient adsorbents for removing $\mathrm{Cr}(\mathrm{VI})$ metal ions from the wastewater, however, they are expensive [56-58]. Zeolites, clays, and silicious materials are low-cost, widely available, and able to modify the adsorption characteristics, natural materials are used in the adsorption [59-61]. Using bio-adsorbents like chitins and chitosan, yeast, fungal biomass, and bacterial biomass, the $\mathrm{Cr}(\mathrm{VI})$ remove from wastewater $[62,63]$.

\section{Biomass-based adsorbents}

Because of their low-cost, eco-friendly nature, vast abundance, and high efficiency, the use of low-cost adsorbents has gained colossal popularity to purify water contaminated by heavy metals. Generally, the categories of these adsorbents include 
agricultural byproducts, animal waste, forest waste, industrial waste, etc. Despite the effectiveness of the commercially available activated carbon in the adsorption of heavy metal ions, its expensiveness limits its use. Hence, it is necessary to develop the adsorbents which are readily available at a relatively low cost, that can be widely employed for the adsorption of heavy metal ions, including $\mathrm{Cr}(\mathrm{VI})$, from the aqueous environment. Although agricultural byproducts are comparatively less effective than commercially available activated carbons, their low cost and high abundance have made them a better option. Agrarian byproducts are composed of starch, sugar, lignin, cellulose, pectin, etc. Several functional groups such as hydroxyl, aldehyde, and ketone groups present in many adsorbents. These qualities of the adsorbents have made them more efficient for the removal of pollutants [64-67].

Fruit peels are readily available from juice industries, which are solid wastes. Mohammed et al.used pomegranate peel as a natural adsorbent for the adsorption of $\mathrm{Cr}(\mathrm{VI})$ ions from industrial wastewater. The authors reported that the experimental data best fitted for the Langmuir isotherm model. They determined the metal removal efficiency to be $90 \%$, with the most excellent adsorption capacity of $9.45 \mathrm{mg} / \mathrm{g}$ [68]. Galil et al. observed the maximum adsorption capacity for $\mathrm{Cr}$ (VI) onto $\mathrm{H}_{2} \mathrm{SO}_{4}$ treated pomegranate peel to be $28.28 \mathrm{mg} / \mathrm{gat}$ the $\mathrm{pH}$ of 3.0. They used the batch adsorption technique to study the influence of various operating factors such as $\mathrm{pH}$, initial concentration, contact time, and biosorbent dose. The equilibrium data fitted best to the Langmuir model, and the kinetics of the process better explained by the pseudo-second-order model [69].

Brans are the byproducts of the grains obtained from milling industries. Ogata et al. prepared virgin wheat bran and calcined wheat bran to remove $\mathrm{Cr}(\mathrm{VI})$. Adsorption isotherm and kinetic data best fitted the Freundlich and pseudo-second-order models, respectively [70]. The husk is also an agricultural waste collected from milling industries. Mullicket al. carried out a comparative study on the capacity of $\mathrm{Cr}(\mathrm{VI})$ adsorption from water by activated carbon derived from rice husk with the commercial one. For this purpose, the rice husk sample was chemically modified with $\mathrm{NaOH}$ solution. They investigated the effects of operational parameters and reported the percentage removal of $\mathrm{Cr}(\mathrm{VI})$ at $\mathrm{pH}$ of 2.0 to be $91.23 \%$ for the rice husk-derived activated carbon. The pseudo-second-order model agreed well with the kinetic data, and the adsorption isotherm best fitted to the Langmuir isotherm model. The study revealed that the adsorption process was endothermic, and the equilibrium constant increased with increasing temperature [71].

Chakraborty et al. studied the adsorption of $\mathrm{Cr}(\mathrm{VI})$ ions from water using sawdust modified with formaldehyde. They investigated the effects of the parameters like $\mathrm{pH}$, contact time, adsorbent dose, and initial metal ion concentration. The authors reported that the experimental data was better explained by the Freundlich isotherm model. The maximum adsorption of $100 \%$ was observed at $\mathrm{pH} 2.0$, initial concentration of $10 \mathrm{mg} / \mathrm{L}$, and adsorbent dose of $4 \mathrm{~g} / \mathrm{L}$. They reported the maximum adsorption capacity to be $8.84 \mathrm{mg} / \mathrm{g}$. The obtained data best fitted with a pseudo-second-order kinetic model, and the adsorption process was endothermic and spontaneous [53]. Li et al. studied the adsorptive removal of $\mathrm{Cr}(\mathrm{VI})$ from water by a walnut shell, chemically modified using diethylenetriamine. The study was carried out by the batch adsorption method. They reported the maximum adsorption of $50.1 \mathrm{mg} / \mathrm{g}$ at $303 \mathrm{~K}$ with a solution $\mathrm{pH}$ of 3 . The experimental data is better explained by the Langmuir isotherm model, and the data is better fitted with a pseudo-second-order kinetic model [72]. Lin et al. carried out the batch adsorption study using aminated rice straw grafted-poly (vinyl alcohol) to remove $\mathrm{Cr}(\mathrm{VI})$ from an aqueous solution. The authors reported that the experimental data was best supported by Freundlich isotherm and Elovich models. They found the maximum adsorption up to $140.39 \mathrm{mg} / \mathrm{g}$ at the $\mathrm{pH}$ of 2.0. The maximum adsorption was much more prominent than that of the unmodified rice straw (34.90 $\mathrm{mg} / \mathrm{g}$ ). The reaction was endothermic, and spontaneous [73].

Prabhakaran et al. reported the $\mathrm{Cr}(\mathrm{VI})$ adsorption capacity of spent tea and coffee dust. $\mathrm{The} \mathrm{Cr}(\mathrm{VI})$ ions get reduced to $\mathrm{Cr}(\mathrm{III})$ ions, and the reduction of $\mathrm{Cr}(\mathrm{III})$ ions was found dependent on the $\mathrm{pH}$ of the solution. The maximum removal of chromium by tea and coffee dust was $44.9 \mathrm{mg} / \mathrm{g}$ and $39.0 \mathrm{mg} / \mathrm{g}$, respectively, at the solution $\mathrm{pH}$ of 4.0 . The experimental data is best described by Langmuir isotherm models [74]. Bhatt et al. prepared the charred sugarcane bagasse (CSB) by chemical modification of sugarcane bagasse with Conc. $\mathrm{H}_{2} \mathrm{SO}_{4}$. They used the batch adsorption technique to study the influence of parameters like $\mathrm{pH}$, contact time, concentration, and doses of the adsorbent. The optimum $\mathrm{pH}$ was determined to be 1 , following the pseudo-secondorder kinetics. The adsorption \% decreased with increasing initial metal concentration and a lower dose of adsorbent. Equilibrium adsorption was fitted the best with Freundlich adsorption isotherm [75].

Activated carbon (AC) can be synthesized by all carbonaceous materials. However, the product's characteristics will alter based on the type of the raw material used, the nature of the activating agent, and the condition and activation processes. AC made from petroleum and coal by using multistep preparation process using of expensive and hazardous chemicals have the high 
specific surface area and good adsorption capacity. Recently, biomass-based waste materials exhibited potential as precursor materials for the synthesis of AC, usually with comparable adsorption capacity with commercial activated carbons [71,76]. The use of biomass-based waste materials in AC preparation would not only help in solving the disposal problem but also help in reducing the cost of carbon preparation. It would provide a potentially inexpensive alternative to existing, extensively used, commercially available petroleum/coal-based activated carbons. AC produced from biomass-based waste materials was found to be the most effective adsorbent for the removal of $\mathrm{Cr}(\mathrm{VI})$ due to its high surface area, various surface functional groups, and microporosity structure. Thus, plenty of researches was carried on the adsorptive removal of $\mathrm{Cr}(\mathrm{VI})$ onto AC derived from different BMWs [76,77]. The particle size exhibited a vital role in adsorption efficiency. Besides, adsorption $\mathrm{Cr}(\mathrm{VI})$ on $\mathrm{AC}$ largely depends on its activation and pretreatment method [78]. Some of the BMWs bio-adsorbents used for the removal of $\mathrm{Cr}(\mathrm{VI})$ are presented in Table 1.

Table 1: Adsorption capacities of various adsorbents for the removal of Cr(VI) ions from water

\begin{tabular}{|c|c|c|c|c|}
\hline Adsorbent & $\begin{array}{c}\text { Optimum } \\
\text { pH }\end{array}$ & $\begin{array}{c}\text { Adsorption } \\
\text { capacity } \\
(\mathrm{mg} / \mathrm{g})\end{array}$ & $\begin{array}{c}\text { Fitted } \\
\text { isotherm } \\
\text { model }\end{array}$ & Reference \\
\hline Pomegranate peel & - & 9.45 & Langmuir & [68] \\
\hline $\mathrm{H}_{2} \mathrm{SO}_{4}$ treated pomegranate peel & 3 & 28.28 & Langmuir & [69] \\
\hline $\mathrm{NaOH}$ treated rice husk & 2 & 34.85 & Langmuir & [71] \\
\hline Formaldehyde treated sawdust & 2 & 8.84 & Freundlich & [53] \\
\hline Diethylenetriamine treated walnut shell & 3 & 50.1 & Langmuir & [72] \\
\hline Aminated rice straw & 2 & 140.39 & Freundlich & [73] \\
\hline Waste tea leaves & 4 & 44.9 & Langmuir & [74] \\
\hline Exhausted ground coffee waste & 4 & 39 & Langmuir & [74] \\
\hline Gliricidiasepium Leaf Powder & 2 & 35.71 & Freundlich & [12] \\
\hline $\mathrm{H}_{3} \mathrm{PO}_{4}$ activated Sugar cane bagasse & 5 & 28.3 & Langmuir & [79] \\
\hline Conc. $\mathrm{H}_{2} \mathrm{SO}_{4}$ treated Grape waste & 4 & $1.91(\mathrm{~mol} / \mathrm{kg})$ & Langmuir & [80] \\
\hline Mangifera Indica & 3 & 320.07 & Langmuir & [81] \\
\hline Sakura waste & 1 & 435.25 & Langmuir & [82] \\
\hline Eucalyptuscamadulensis seeds & 1 & 51.93 & Langmuir & [83] \\
\hline Benincasahispida peel & 1 & 18.7 & Freundlich & [84] \\
\hline Sewage sludge biomass & $2-10$ & 1.87 & $\begin{array}{l}\text { Langmuir/ } \\
\text { Freundlich }\end{array}$ & [85] \\
\hline $\mathrm{H}_{3} \mathrm{PO}_{4}$ activated apple peels & 2 & 36.01 & Freundlich & [86] \\
\hline $\mathrm{H}_{3} \mathrm{PO}_{4}$ activated sugar beet bagasse & 4 & 52.8 & Langmuir & [87] \\
\hline $\mathrm{KOH}$ activated Bermuda grass & 2 & 403.2 & Langmuir & [88] \\
\hline Ozone activated rice husk & 2 & 8.5 & Freundlich & [89] \\
\hline $\mathrm{NaOH}$ activated longan seed & 3 & 169.5 & Langmuir & [90] \\
\hline
\end{tabular}

Adsorption isotherm generally provides information about adsorption behaviour between the adsorbent and adsorbate and the surface properties of the adsorbent. Generally, two typical isotherm models, Langmuir and Freundlich models, were fit the experimental adsorption data and assessed the isotherm performance. Most biomass-based adsorbents reported to follow Langmuir adsorption isotherm, and few of them reported to follow Freundlich Adsorption. Better fit with the Langmuir isotherm model indicates that $\mathrm{Cr}(\mathrm{VI})$ ions from monolayer on a homogeneous surface of the adsorbents without interaction between 
adsorbed molecules and all the adsorption sites are energetically equivalent [68-71, 79-83]. However, the Freundlich isotherm model considers multilayer adsorption of $\mathrm{Cr}(\mathrm{VI})$ on the heterogeneous surface of the adsorbents, and the adsorption energy exponentially decreases on completion of the adsorption sites of adsorbents $[46,66,86]$. The mechanism of adsorption of metal ions includes chemisorption, surface adsorption, adsorption-complexation, ligand exchange, and microprecipitation[25]. The proposed possible interactions between $\mathrm{Cr}(\mathrm{VI})$ and adsorbents [91] are adsorptions through electrostatic attraction between $\mathrm{Cr}(\mathrm{VI})$ anion and positive functional groups of adsorbent and adsorption of $\mathrm{Cr}(\mathrm{VI})$ followed by complete reduction to $\mathrm{Cr}(\mathrm{III})$. The reduction is carried out by the donation of electrons from donor atoms such as $\mathrm{O}, \mathrm{S}$, and $\mathrm{N}$ of the adjacent functional group of adsorbents during $\mathrm{Cr}(\mathrm{VI})$ adsorption. The mechanism of biosorption of hexavalent chromium onto $\mathrm{AC}$ was reported as the reduction of $\mathrm{Cr}(\mathrm{VI})$ to $\mathrm{Cr}(\mathrm{III})$ on the adsorbent surface, followed by $\mathrm{Cr}(\mathrm{III})[25,80,91]$.

Biomass-based adsorbents exhibit satisfactory \% removal of $\mathrm{Cr}(\mathrm{VI})$ to the commercial adsorbents but are still lower than the conventional methods. However, in developing countries like Nepal, biosorption is considered to be an effective water treatment method compared to conventional methods due to its simplicity and flexibility of design, ease of operation and maintenance, cheap, minimal sludge generation, the potential for regeneration, and can be used in water having trace level of contaminants.

\section{The chemistry of $\mathrm{Cr}(\mathrm{VI})$ and the effect of pH}

Chromium exists in several oxidation states ranges from 0 to VI. However, only $\mathrm{Cr}(\mathrm{III})$ and $\mathrm{Cr}(\mathrm{VI})$ are stable to exist in the environment. $\mathrm{The} \mathrm{Cr}(\mathrm{III})$ is the most stable oxidation state. Hexavalent chromium forms various species such as $\mathrm{Cr}_{2} \mathrm{O}_{7}^{2-}$, $\mathrm{HCr}_{2} \mathrm{O}_{7}^{-}, \mathrm{CrO}_{4}^{2-}, \mathrm{HCrO}_{4}^{-}$. The relative proportions of $\mathrm{Cr}(\mathrm{VI})$ are dependent on both $\mathrm{pH}$ and total $\mathrm{Cr}(\mathrm{VI})$ concentration which was shown in Figure 1 [92].

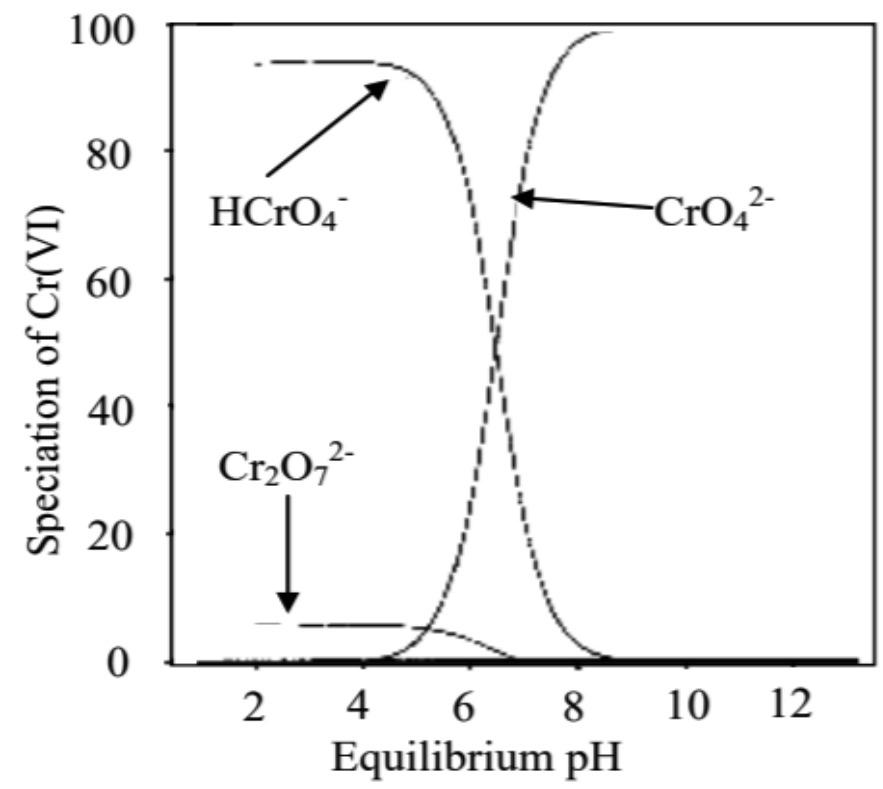

Fig 1: Chemical equilibrium speciation of $\mathrm{Cr}(\mathrm{VI})$

In a basic medium, at $\mathrm{pH}>6$, it forms chromate ion $\mathrm{CrO}_{4}{ }^{2-}$ ion. In an acidic medium, at $\mathrm{pH}$ between 1 and $6, \mathrm{HCrO}_{4}^{-}$and $\mathrm{Cr}_{2} \mathrm{O}_{7}^{2-}$ ions are in equilibrium, but $\mathrm{HCrO}_{4}^{-}$is the prevalent species as shown in Figure 1. At $\mathrm{pH}<1$ the main species is $\mathrm{H}_{2} \mathrm{CrO}_{4}$ $[80,93]$. The main equilibriums for the $\mathrm{Cr}(\mathrm{VI})$ species in water are reported below $[94,95]$ :

$$
\begin{array}{ll}
\mathrm{H}_{2} \mathrm{CrO}_{4} \longrightarrow \mathrm{H}^{+}+\mathrm{HCrO}_{4}^{-} & \mathrm{K}_{1}=0.37 \\
\mathrm{HCrO}_{4}^{-} \longrightarrow \mathrm{H}^{+}+\mathrm{CrO}_{4}^{2-} & \mathrm{K}_{2}=3.2 \times 10^{-7} \\
2 \mathrm{HCrO}_{4}^{-} \longrightarrow \mathrm{Cr}_{2} \mathrm{O}_{7}^{2-}+\mathrm{H}_{2} \mathrm{O} & \mathrm{K}_{3}=35.5
\end{array}
$$

$\mathrm{Cr}$ (VI) in acidic solution exhibits a very high positive redox potential which indicates that it is highly oxidizing in the presence of electron donating species $[80,96]$. 


$$
\mathrm{Cr}_{2} \mathrm{O}_{7}^{2-}+14 \mathrm{H}^{+}+6 \mathrm{e}^{-} \longrightarrow 2 \mathrm{Cr}^{3+}+7 \mathrm{H}_{2} \mathrm{O} \quad \mathrm{E}^{\mathrm{o}}=1.33 \mathrm{~V}
$$

However, The $\mathrm{CrO}_{4}^{-}$ion in alkaline solution is much less oxidizing:

$$
\mathrm{CrO}_{4}^{2-}+4 \mathrm{H}_{2} \mathrm{O}+3 \mathrm{e}^{-} \longrightarrow \mathrm{Cr}(\mathrm{OH})_{3}(\mathrm{~s})+5 \mathrm{OH}^{-} \quad \mathrm{E}^{\mathrm{o}}=-0.13 \mathrm{~V}
$$

In a more alkaline solution the reduction of $\mathrm{CrO}_{4}^{2-}$ generates $\mathrm{OH}^{-}$against a gradient. This destabilizes $\mathrm{Cr}$ (III) compared to the $\mathrm{Cr}(\mathrm{VI})$ resulting in a decrease in the redox potential with the increase in basic strength [97].

The prevalent form of $\mathrm{Cr}(\mathrm{VI})$ at $\mathrm{pH}=2-6$ is $\mathrm{HCrO}_{4}^{-}$. At this $\mathrm{pH}$ range, a large number of $\mathrm{H}^{+}$ions exists in the solution, and the surface protonation of the adsorbent leads to the formation of positively charged on the surface of the adsorbent. These positively charged surfaces of adsorbents interact with $\mathrm{Cr}(\mathrm{VI})$ anion by an electrostatic attraction so that prevalent species $\mathrm{HCrO}_{4}^{-}$is strongly adsorbed onto the surface of the adsorbent. Hence, adsorption is more favorable in this $\mathrm{pH}$ range [96]. At higher $\mathrm{pH}$, a high concentration of $\mathrm{OH}$ - ions strongly compete with $\mathrm{CrO}_{4}{ }^{2}$ ions for the adsorption site, and thus, \% adsorption of $\mathrm{Cr}$ (VI) sharply decreases at higher $\mathrm{pH}[80]$. At $\mathrm{pH}<2$, even though the medium is strongly acidic, a very high concentration of $\mathrm{H}^{+}$ions is available, which can promote the reduction of $\mathrm{Cr}(\mathrm{VI})$ to $\mathrm{Cr}(\mathrm{III})$. The cationic ions interact with the protonated surface of the adsorbent by electrostatic repulsion, and there is a competition between $\mathrm{H}^{+}$ions, $\mathrm{Cr}$ (III) species, and the adsorption surface active sites. Hence, the decrease in adsorption of $\mathrm{Cr}(\mathrm{VI})$ at very low $\mathrm{pH}$ is due to the reduction of $\mathrm{Cr}(\mathrm{VI})$ to $\mathrm{Cr}$ (III) [93]. The decrease in the rate of adsorption is due to the coexistence of $\mathrm{Cr}_{2} \mathrm{O}_{7}{ }^{2-}$ and $\mathrm{CrO}_{4}{ }^{2-}$ with $\mathrm{HCrO}_{4}^{-}$in the solution medium; thus, causing competition on the adsorption sites [98]. The chemistry of $\mathrm{Cr}(\mathrm{VI})$ is strongly dependent on pH. Table 2 reports the prevalent species of $\mathrm{Cr}(\mathrm{VI})$ at each $\mathrm{pH}$ range [99].

Table 2: Composition of $\mathrm{Cr}$ (VI) as a function of $\mathrm{pH}$

\begin{tabular}{ll}
\hline $\mathbf{p H}$ & Prevalent species of Cr(VI) \\
\hline$<1$ & $\mathrm{H}_{2} \mathrm{CrO}_{4}$ (chromic acid) \\
$2-4$ & $\mathrm{Cr}_{2} \mathrm{O}_{7}^{2-}$ (dichromate) \\
$4-6$ & $\mathrm{HCrO}_{4}^{-}$(hydrogen chromate) $\mathrm{Cr}_{2} \mathrm{O}_{7}^{2-}$ (dichromate) \\
$6-8$ & $\mathrm{Cr}_{2} \mathrm{O}_{7}^{2-}$ (dichromate) $\mathrm{CrO}_{4}^{2-}$ (chromate) \\
$>8$ & $\mathrm{CrO}_{4}^{2-}$ (chromate) \\
\hline
\end{tabular}

\section{Future Prospectives}

Biomass-based waste materials (BMWs) are a better alternative to the commercially available activated carbon for heavy metal removal from an aqueous environment. Due to their easy accessibility and economical and environmental friendliness, demand and uses of biomass-based adsorbents expected to rise shortly. Future studies must explore highly effective, costsaving, and environment-friendly adsorbents that can easily regenerate from many operational cycles without significant loss of adsorption efficiency. In the future, the research should extend using the continuous column method on the natural wastewater and industrial effluents to enhance the large-scale application of the adsorbents. Further work needs to explore a cost-benefit analysis of the application of BMWs as adsorbents for the removal and recovery of $\mathrm{Cr}(\mathrm{VI})$ as well as other heavy metals.

\section{Conclusions}

Heavy metal pollution has been causing severe environmental issues around the globe. In an attempt to find the remedial action, numerous conventional techniques such as reverse osmosis, ion exchange, precipitation, coagulation, membrane separation, and adsorption methods are used for their removal. Among them, the adsorption method is found very practical and helpful for the purpose. Despite the higher efficiency of commercially available activated carbon, its high cost limits its use. It is hence economic and practical to use biomass-based waste materials due to their low cost, easy availability, easy separation, high adsorption capacity, and renewability. The chemically modified adsorbents are found more effective in comparison to unmodified adsorbents. Even though various research articles are available on biomass-based adsorbents, most of them are limited to batchscale. There is no further scale-up of the process for the treatment of natural industrial wastewater. Hence, further research is 
necessary for this area. It is also reasonable to understand that advancement in the current modification methods to develop novel biomass-based adsorbents for removing $\mathrm{Cr}(\mathrm{VI})$ and other heavy metals from water is still an emerging field of research.

\section{References}

1. F. Gode, E. Pehlivan. Removal of Cr(VI) from Aqueous Solution by Two Lewatit-Anion Exchange Resins, Journal of Hazardous Materials, 2005, 119, 175-182. (DOI:https://doi.org/10.1016/j.jhazmat.2004.12.004).

2. T. Karthikeyan, S. Rajgopal, L.R. Miranda. Chromium (VI) Adsorption from Aqueous Solution by Hevea Brasilinesis Sawdust Activated Carbon, Journal of Hazardous Materials, 2005, 124, 192-199. (DOI:https://doi.org/10.1016/j. jhazmat.2005.05.003).

3. R.R. Patterson, S. Fendorf, M. Fendorf. Reduction of Hexavalent Chromium by Amorphous Iron Sulfide, Environmental Science and Technology, 1997, 31, 2039-2044. (DOI:https://doi.org/10.1021/es960836v).

4. S.J. Park, Y.S. Jang. Pore Structure and Surface Properties of Chemically Modified Activated Carbons for Adsorption Mechanism and Rate of Cr(VI), Journal of Colloid and Interface Science, 2002, 249, 458-463. (DOI:https://doi. org/10.1006/jcis.2002.8269).

5. D. Mohan, C.U.Pittman Jr. Activated Carbons and Low-Cost Adsorbents for Remediation of Tri-and Hexavalent Chromium from Water, Journal of hazardous materials, 2006, 137, 762-811. (DOI: https://doi.org/10.1016/j.jhazmat.2006.06.060 ).

6. W. Mertz. Chromium in Human Nutrition: A Review, The Journal of nutrition, 1993, 123, 626-633. (DOI: https://doi. org/10.1093/jn/123.4.626).

7. M.S. Karmacharya, V.K. Gupta, V. K Jha. Preparation of Activated Carbon from Waste Tire Rubber for the Active Removal of Cr (VI) and Mn (II) Ions from Aqueous Solution, Transactions of the Indian Ceramic Society, 2016, 75, 234-241. (DOI: https://doi.org/10.1080/0371750X.2016.1228481).

8. J.T. Haney Jr, N. Erraguntla, R.L. Sielken Jr, C. Valdez-Flores. Development of a Cancer-Based Chronic Inhalation Reference Value for Hexavalent Chromium Based on a Nonlinear-threshold Carcinogenic Assessment, Regulatory toxicology and pharmacology, 2012, 64, 466-480. (DOI: https://doi.org/10.1016/j.yrtph.2012.10.008).

9. R.M. Sedman, J.A.Y. Beaumont, T.A. McDonald, S. Reynolds, G. Krowech, R. Howd. Review of the Evidence Regarding the Carcinogenicity of Hexavalent Chromium in Drinking Water, Journal of environmental science and health part C, 2006, 24, 155-182. https://doi.org/10.1080/10590500600614337

10. D.L. Adhikari, R.L. Aryal, S. Bhattarai, S.K. Gautam, B. R. Poudel. Removal of Chromium (VI) from Aqueous Solution Using Chemically Modified Sweet Lime (Citrus limetta) Peels as Adsorbent, Journal Nepal Chemical Society, 2017, 36, 82-95. (DOI: https://doi.org/10.3126/jncs.v36i0.34613).

11. Y. Zhang, G. Lan, Y. Liu, T. Zhang, H. Qiu, F. Li, J. Yan, Y. Lu. Enhanced Adsorption of Cr (VI) from Aqueous Solution by Zirconium Impregnated Chitosan Microspheres: Mechanism and Equilibrium. Separation Science and Technology, 2020, 1-14. (DOI: https://doi.org/10.1080/01496395.2020.1842451).

12. E. Suganya, N. Saranya, C. Patra, L.A. Varghese, N. Selvaraju. Biosorption Potential of Gliricidiasepium Leaf Powder to Sequester Hexavalent Chromium from Synthetic Aqueous Solution, Journal of Environmental Chemical Engineering, 2019, 7(3), 103-112. (DOI: https://doi.org/10.1016/j.jece.2019.103112).

13. El Nemr. Pomegranate Husk as an Adsorbent in the Removal of Toxic Chromium from Wastewater, Chemistry and Ecology, , 2007, 23, 409-425. (DOI:https://doi.org/10.1080/02757540701653350).

14. A. Ajmani, T. Shahnaz, S. Narayanan, S. Narayanasamy. Equilibrium, Kinetics and Thermodynamics of Hexavalent Chromium Biosorption on Pristine and Zinc Chloride Activated Sennasiamea Seed Pods, Chemistry and Ecology, 2019, 35(4), 379-396. (DOI:https://doi.org/10.1080/02757540.2019.1584614). 
15. B.R. Poudel, R.L. Aryal, S. Bhattarai, A.R. Koirala, S.K. Gautam, K.N. Ghimire, B. Pant, M. Park, H. Paudyal, M.R. Pokhrel. Agrowaste Derived Biomass Impregnated with $\mathrm{TiO}_{2}$ as a Potential Adsorbent for Removal of As(III) from Water, Catalysts, 2020, 10, 1125. (DOI:https://doi.org/10.3390/catal10101125).

16. M.R. Pokhrel, B R. Poudel, R.L. Aryal, H. Paudyal, K.N. Ghimire. Removal and Recovery of Phosphate from Water and Wastewater using Metal-loaded Agricultural Waste-based Adsorbents: A Review, Journal of Institute of Science and Technology, 2019, 24(1), 77-89. (DOI:https://doi.org/10.3126/jist.v24i1.24640).

17. R.L. Aryal, B.R. Poudel, S.K. Gautam, H. Paudyal, M.R. Pokhrel, K.N. Ghimire. Removal of Fluoride from Aqueous Solution Using Biomass-based Adsorbent: A Review, Journal of Nepal Chemical Society, 2019, 40, 44-51. (DOI:https:// doi.org:10.3126/jncs.v40i0.27281).

18. B.R. Poudel, R.L. Aryal, L.B. Khadka, K.N. Ghimire, H. Paudyal, M.R. Pokhrel. Development of Biomass-based Anion Exchanger for the Removal of Trace Concentration of Phosphate from Water, Journal of Nepal Chemical Society, 2020, 41, 56-63. (DOI:https://doi.org/10.3126/jncs.v41i1.30488).

19. S. Babel, T.A. Kurniawan. Low-cost Adsorbents for Heavy Metals Uptake from Contaminated Water: A Review, Journal of Hazardous Materials, 2003, 97, 219-243. (DOI:https://doi.org/10.1016/S0304-3894(02)00263-7).

20. A. Shrestha, B.R. Poudel, M. Silwal, M. R. Pokhrel. Adsorptive Removal of Phosphate onto Iron Loaded Litchi chinesis Seed Waste, Journal of Institute of Science and Technology, 2018, 23, 81-87. (DOI:https://doi.org/10.3126/jist. v23i1.22200).

21. A. Bingol, H. Ucun, Y.K. Bayhan, A. Karagunduz, A. Cakici, B. Keskinler. Removal of Chromate Anions from Aqueous Stream by a Cationic Surfactant-modified Yeast, Bioresource Technology, 2004, 94, 245-249. (DOI:https://doi. org/10.1016/j.biortech.2004.01.018).

22. B.S. Krishna, D.S.R. Murty, B.S. Jai Prakash. Thermodynamics of Chromium(VI) Anionic Species Sorption onto Surfactant-Modified Montmorillonite Clay, Journal of Colloid and Interface Science, 2000, 229, 230-236. (DOI:https:// doi.org/10.1006/jcis.2000.7015).

23. I. Lagiopoulos, A. Binteris, T. Mpouras, I. Panagiotakis, M. Chrysochoou, D. Dermatas. Potential Biosorbents for Treatment of Chromium(VI) Contaminated Water Discharged into Asopos River, International Journal of Environmental Science and Technology, 2017, 14, 1481-1488. (DOI: https://doi.org/10.1007/s13762-017-1254-x)

24. O.S. Bello, O.M. Atoyebi, K.A. Adegoke, E.O. Fehintola, A.O. Ojo. Removal of Toxicant Chromium (VI) from Aqueous Solution Using Different Adsorbents, Journal of the Chemical Society of Pakistan, 2015, 37, 190-206.

25. H. Karimi-Maleh, Y. Orooji, A. Ayati, S. Qanbari, B. Tanhaei, F. Karimi, M. Alizadeh, J. Rouhi, L. Fu, M. Sillanpää. Recent Advances in Removal Techniques of Cr(VI) Toxic Ion from Aqueous Solution: A comprehensive review, Journal of Molecular Liquids, 2021, 329, 115062. (DOI: https://doi.org/10.1016/j.molliq.2020.115062).

26. I. Anastopoulos, V.A. Anagnostopoulos, A. Bhatnagar, A.C. Mitropoulos, G.Z. Kyzas. A Review for Chromium Removal by Carbon Nanotubes, Chemistry and Ecology, 2017, 33, 572-588. (DOI: https://doi.org/10.1080/02757540.2017.132 8503).

27. E.I. Ugwu, J.C. Agunwamba. A Review on the Applicability of Activated Carbon Derived from Plant Biomass in Adsorption of Chromium, Copper, and Zinc from Industrial Wastewater, Environmental Monitoring and Assessment, 2020, 192, 240. (DOI: https://doi.org/10.1007/s10661-020-8162-0).

28. S. Lal, A.Singhal, P. Kumari. Exploring Carbonaceous Nanomaterials for Arsenic and Chromium Removal from Wastewater, Journal of Water Process Engineering, 2020,36, 101276. (DOI: https://doi.org/10.1016/j.jwpe.2020.101276).

29. X. Sheng, H. Shi, L. Yang, P. Shao, X. Luo. Rationally Designed Conjugated Microporous Polymers for Contaminants Adsorption, Science of the Total Environment, 2021, 750, 141683.(DOI: https://doi.org/10.1016/j.scitotenv.2020.141683). 
30. M.K. Dinker, P.S. Kulkarni. Recent Advances in Silica-Based Materials for the Removal of Hexavalent Chromium: A Review, Journal of Chemical and Engineering Data, 2015, 60, 2521-2540. (DOI:https://doi.org/10.1021/acs. jced.5b00292).

31. S.H. Rimu, M.M. Rahman. Insight of Chitosan-Based Nanocomposite for Removal of Hexavalent Chromium from Wastewater- A Review, International Journal of Environmental Analytical Chemistry, 2020 (DOI: https://doi.org/10.10 80/03067319.2020.1817426).

32. R. Acharya, K. Parida. A Review on Adsorptive Remediation of Cr(VI) by Magnetic Iron Oxides and Their Modified forms, Biointerface Research in Applied Chemistry, 2020, 10, 5266-5272. (DOI: https://doi.org/10.33263/BRIAC102.266272)

33. O. Access, H.A. Maitlo, K.-H. Kim, V. Kumar, S. Kim, J.-W. Park, Nanomaterials-Based Treatment Options for Chromium in Aqueous Environments, Environment International, 2019, 130, 104748. (DOI:https://doi.org/10.1016/j. envint.2019.04.020).

34. Z.H. Farooqi, M.W. Akram, R. Begum, W. Wu, A. Irfan, Inorganic Nanoparticles for Reduction of Hexavalent Chromium: Physicochemical Aspects, Journal of Hazardous Materials, 2021, 402, 123535. (DOI: https://doi.org/10.1016/j. jhazmat.2020.123535).

35. Y. Jiang, Z. Liu, G. Zeng, Y. Liu, B. Shao, Z. Li, Y. Liu, W. Zhang, Q. He. Polyaniline-Based Adsorbents for Removal of Hexavalent Chromium from Aqueous Solution: A Mini-Review, Environmental Science and Pollution Research, 2018, 25, 6158-6174. (DOI: https://doi.org/10.1007/s11356-017-1188-3).

36. Y.-X. Li, Y.-C. Han, C.-C. Wang. Fabrication Strategies and Cr(VI) Elimination Activities of the MOF Derivatives and their Composites, Chemical Engineering Journal, 2021, 405, 126648. (DOI: https://doi.org/10.1016/j.cej.2020.126648).

37. V. Dimos, K.J. Haralambous, S. Malamis. A Review on the Recent Studies for Chromium Species Adsorption on Raw and Modified Natural Minerals, CriticalReviews in Environmental Science and Technology, 2012, 42, 1977-2016. (DOI: https://doi.org/10.1080/10643389.2011.574102).

38. W. Jianlong, Z. Xinmin, Q. Yi. Removal of Cr(VI) from Aqueous Solution by Macroporous Resin Adsorption, Journal of Environmental Science and Health, Part A, 2000, 35, 1211-1230. (DOI: https://doi.org/10.1080/10934520009377029).

39. S. Rengaraj, C.K. Joo, Y. Kim, J. Yi. Kinetics of Removal of Chromium from Water and Electronic Process Wastewater by Ion Exchange Resins: 1200H, 1500H and IRN97H, Journal of Hazardous Materials, 2003, 102, 257-275. (DOI:https:// doi.org/10.1016/S0304-3894(03)00209-7).

40. N. Sapari, A. Idris, N. Hisham. Total Removal of Heavy Metal from Mixed Plating Rinse Wastewater, Desalination, 1996, 106, 419-422.(DOI: https://doi.org/10.1016/S0011-9164(96)00139-7).

41. S.H. Lin, C.D. Kiang. Chromic Acid Recovery from Waste Acid Solution by an Ion Exchange Process: Equilibrium and Column Ion Exchange Modeling, Chemical Engineering Journal, 2003, 92, 193-199.(DOI:https:/doi.org/10.1016/ S1385-8947(02)00140-7).

42. A.A. Bhatti, S. Memon, N. Memon, A.A. Bhatti, I.B. Solangi. Evaluation of Chromium(VI) Sorption Efficiency of Modified Amberlite XAD-4 Resin, Arabian Journal of Chemistry, 2017, 10, S1111-S1118. (DOI:https://doi. org/10.1016/j.arabjc.2013.01.020).

43. S.A. Cavaco, S. Fernandes, M.M. Quina, L.M. Ferreira. Removal of Chromium from Electroplating Industry Effluents by Ion Exchange Resins, Journal of Hazardous Materials, 2007, 144, 634-638. (DOI:https://doi.org/10.1016/j. jhazmat.2007.01.087).

44. H.A. Aziz, Mohd.N. Adlan, K.S. Ariffin. Heavy Metals (Cd, Pb, Zn, Ni, Cu and Cr(III) Removal from Water in Malaysia: Post Treatment by High Quality Limestone, Bioresource Technology, 2008, 99, 1578-1583. (DOI:https://doi. org/10.1016/j.biortech.2007.04.007).

45. F. Fu, Q. Wang. Removal of Heavy Metal Ions from Wastewaters: A Review, Journal of Environmental Management, 2011, 92, 407-418. (DOI:https://doi.org/10.1016/j.jenvman.2010.11.011). 
46. Q. Chang, G. Wang. Study on the Macromolecular Coagulant PEX which Traps Heavy Metals, Chemical Engineering Science, 2007, 62, 4636-4643. (DOI:https://doi.org/10.1016/j.ces.2007.05.002).

47. T.A. Kurniawan, G.Y.S. Chan, W.-H. Lo, S. Babel. Physico-chemical Treatment Techniques for Wastewater Laden with Heavy Metals, Chemical Engineering Journal, 2006, 118, 83-98. (DOI:https://doi.org/10.1016/j.cej.2006.01.015).

48. S. Al-Amshawee, M.Y.B.M. Yunus, A.A.M. Azoddein, D.G. Hassell, I.H. Dakhil, H.A. Hasan, Electrodialysis Desalination for Water and Wastewater: A Review, Chemical Engineering Journal, 2020, 380, 122231. (DOI:https://doi. org/10.1016/j.cej.2019.122231).

49. R.C.A. Moura, D.A. Bertuol, C.A. Ferreira, F.D.R. Amado. Study of Chromium Removal by the Electrodialysis of Tannery and Metal-Finishing Effluents, International Journal of Chemical Engineering, 2012, Vol 1-7.(DOI:https://doi. org/10.1155/2012/179312)

50. C.A. Kozlowski, W. Walkowiak. Removal of Chromium(VI) from Aqueous Solutions by Polymer Inclusion Membranes, Water Research, 2002, 36, 4870-4876. (DOI:https://doi.org/10.1016/S0043-1354(02)00216-6).

51. A. Mnif, I. Bejaoui, M. Mouelhi, B. Hamrouni. Hexavalent Chromium Removal from Model Water and Car Shock Absorber Factory Effluent by Nanofiltration and Reverse Osmosis Membrane, International Journal of Analytical Chemistry, 2017, Vol, Issue, page. (DOI:https://doi.org/10.1155/2017/7415708).

52. E. Dialynas, E. Diamadopoulos. Integration of a Membrane Bioreactor Coupled with Reverse Osmosis for Advanced Treatment of Municipal Wastewater, Desalination,2009, 238,302-311.(DOI:https://doi.org/10.1016/j.desal.2008.01.046)

53. R. Chakraborty, R. Verma, A. Asthana, S.S. Vidya, A.K. Singh, Adsorption of Hazardous Chromium (VI) Ions from Aqueous Solutions Using Modified Sawdust: Kinetics, Isotherm and Thermodynamic Modelling, International Journal of Environmental Analytical Chemistry, 2019, Vol (issue), 1-18. (DOI:https://doi.org/10.1080/03067319.2019.167374 3).

54. R. Chakraborty, A. Asthana, A.K. Singh, B. Jain, A.B.H. Susan. Adsorption of Heavy Metal Ions by Various Lowcost Adsorbents: A Review, International Journal of Environmental Analytical Chemistry, 2020, vol (issue),1-38. (DOI:https://doi.org/10.1080/03067319.2020.1722811).

55. M.T. Yagub, T.K. Sen, S.Afroze, H.M. Ang. Dye and its Removal from Aqueous Solution by Adsorption: A Review, Advances in Colloid and Interface Science, 2014, 209, 172-184. (DOI:https://doi.org/10.1016/j.cis.2014.04.002).

56. M.A. Atieh, Removal of Chromium (VI) from Polluted Water Using Carbon Nanotubes Supported with Activated Carbon, Procedia Environmental Sciences, 2011, 4, 281-293. (DOI: https://doi.org/10.1016/j.proenv.2011.03.033).

57. A.A. Attia, S.A. Khedr, S.A. Elkholy. Adsorption of Chromium Ion(VI) by Acid Activated Carbon, Brazilian Journal of Chemical Engineering, 2010, 27, 183-193. (DOI: https://doi.org/10.1590/S0104-66322010000100016).

58. Gopalakrishnan, R. Krishnan, S. Thangavel, G. Venugopal, S.-J. Kim. Removal of Heavy Metal Ions from Pharmaeffluents Using Graphene-oxide Nanosorbents and Study of their Adsorption Kinetics, Journal of Industrial and Engineering Chemistry, 2015, 30, 14-19. (DOI:https://doi.org/10.1016/j.jiec.2015.06.005).

59. M. Ansari, A. Aroujalian, A. Raisi, B. Dabir, M. Fathizadeh. Preparation and Characterization of Nano-NaX Zeolite by Microwave Assisted Hydrothermal Method, Advanced Powder Technology, 2014, 25, 722-727. (DOI:https://doi. org/10.1016/j.apt.2013.10.021).

60. T.N.T. Phan, M. Bacquet, M. Morcellet. Synthesis and Characterization of Silica Gels Functionalized with Monochlorotriazinyl $\beta$-Cyclodextrin and their Sorption Capacities Towards Organic Compounds, Journal of Inclusion Phenomena and Macrocyclic Chemistry,2000, 38, 345-359. (DOI:https://doi.org/10.1023/A:1008169111023).

61. M. Qurie, M. Khamis, A. Manassra, I. Ayyad, S. Nir, L. Scrano, S.A. Bufo, R. Karaman, Removal of Cr(VI) from Aqueous Environments Using Micelle-Clay Adsorption, The Scientific World Journal, 2013(2013) 942703. (DOI: https://doi.org/10.1155/2013/942703). 
62. Md. Ahmaruzzaman, Adsorption of Phenolic Compounds on Low-cost Adsorbents: A Review, Advances in Colloid and Interface Science, 2008, 143, 48-67. (DOI:https://doi.org/10.1016/j.cis.2008.07.002).

63. J. Wang, C. Chen. Biosorption of Heavy Metals by Saccharomyces cerevisiae: A Review, Biotechnology Advances, 2006, 24, 427-451. (DOI:https://doi.org/10.1016/j.biotechadv.2006.03.001).

64. I. Khazaei, M. Aliabadi, H. Mosavian. Use of Agricultural Waste for Removal of Cr(VI) from Aqueous Solution, Iranian Journal of Chemical Engineering, 2011, 8, 11-23.

65. C.K. Jain, D.S. Malik, A.K. Yadav. Applicability of Plant-Based Biosorbents in the Removal of Heavy Metals: A Review, Environmental Processes, 2016, 3, 495-523. (DOI:https://doi.org/10.1007/s40710-016-0143-5).

66. S.H. Hasan, K.K. Singh, O. Prakash, M. Talat, Y.S. Ho. Removal of Cr(VI) from Aqueous Solutions Using Agricultural Waste 'Maize Bran,' Journal of Hazardous Materials, 2008, 152, 356-365. (DOI:https://doi.org/10.1016/j. jhazmat.2007.07.006).

67. W.S. Wan Ngah, M.A.K.M. Hanafiah, Removal of Heavy metal Ions from Wastewater by Chemically Modified Plant Wastes as Adsorbents: A Review, BioresourceTechnology, 2008, 99, 3935-3948. (DOI:https://doi.org/10.1016/j. biortech.2007.06.011).

68. T. Mohammed, R. Ibrahim, A. Naji. Experimental Investigation and Thermodynamic Study of Heavy Metal Removal from Industrial Wastewater using Pomegranate Peel, MATEC Web of Conferences, 2018, 162, 05007. (DOI:https://doi. org/10.1051/matecconf/201816205007).

69. E.A. Abdel-Galil, L.M.S. Hussin, W.M. El-Kenany. Adsorption of $\mathrm{Cr}(\mathrm{VI})$ from Aqueous Solutions onto Activated Pomegranate Peel Waste, Desalination and Water Treatment, 2021, 211, 250-266. (DOI:https://doi.org/10.5004/ dwt.2021.26588).

70. F. Ogata, N. Nagai, R. Itami, T. Nakamura, N. Kawasaki, Potential of Virgin and Calcined Wheat Bran Biomass for the Removal of Chromium(VI) Ion from a Synthetic Aqueous Solution, Journal of Environmental Chemical Engineering, 2020, 8, 103710. (DOI:https://doi.org/10.1016/j.jece.2020.103710).

71. A. Mullick, S. Moulik, S. Bhattacharjee, Removal of Hexavalent Chromium from Aqueous Solutions by Low-Cost Rice Husk-Based Activated Carbon: Kinetic and Thermodynamic Studies, Indian Chemical Engineer, 2018, 60, 58-71. (DOI:https://doi.org/10.1080/00194506.2017.1288173).

72. J. Li, J. Ma, Q. Guo, S. Zhang, H. Han, S. Zhang, R. Han, Adsorption of Hexavalent Chromium using Modified Walnut Shell from Solution, Water Science and Technology, 2020, 81, 824-833. (DOI:https://doi.org/10.2166/wst.2020.165).

73. C. Lin, W. Luo, T. Luo, Q. Zhou, H. Li, L. Jing, A study on Adsorption of Cr(VI) by Modified Rice Straw: Characteristics, Performances and Mechanism, Journal of Cleaner Production, 2018, 196, 626-634. (DOI:https://doi.org/10.1016/j. jclepro.2018.05.279).

74. S.K. Prabhakaran, K. Vijayaraghavan, R. Balasubramanian, Removal of $\mathrm{Cr}(\mathrm{VI})$ Ions by Spent Tea and Coffee Dust: Reduction to Cr(III) and Biosorption, Industrial and Engineering Chemistry Research, 2009, 48, 2113-2117.(DOI:https:// doi.org/10.1021/ie801380h).

75. P.R. Bhatt, R.L. Aryal, B.R. Poudel, S. Bhattarai, S.K. Gautam. Adsorptive Removal of Cr (VI) from Aqueous Solution onto Charred Sugar Cane Bagasse, Journal of Nepal Chemical Society, 2018, 39, 62-69.(DOI:https://doi.org/10.3126/ jncs.v39i0.27035).

76. I. Enniya, L. Rghioui, A. Journal. Adsorption of Hexavalent Chromium in Aqueous Solution on Activated Carbon Prepared from Apple Peels, Sustainable Chemistry and Pharmacy, 2018, 7, 9-16.(DOI:https://doi.org/10.1016/j. scp.2017.11.003).

77. X.Zhang, L. Zhang, A. Li. Eucalyptus Sawdust Derived Biochar Generated by Combining the Hydrothermal Carbonization and Low Concentration KOH Modification for Hexavalent Chromium Removal, Journal of Environmental. Management, 2018, 206, 989-998. (DOI:https://doi.org/10.1016/j.jenvman.2017.11.079). 
78. J. Zhao, L. Yu, H. Ma, F. Zhou, K. Yang, G. Wu. Corn Stalk-Based Activated Carbon Synthesized by a Novel Activation Method for High-Performance Adsorption of Hexavalent Chromium in Aqueous Solutions, Journal of Colloid and Interface Science, 2020, 578, 650-659. (DOI:https://doi.org/10.1016/j.jcis.2020.06.031).

79. L. Giraldo-Gutiérrez, J.C. Moreno-Piraján, $\mathrm{Pb}(\mathrm{II})$ and $\mathrm{Cr}(\mathrm{VI})$ Adsorption from Aqueous Solution on Activated Carbons Obtained from Sugar Cane Husk and Sawdust, Journal of Analytical and Applied Pyrolysis, 2008, 81, 278-284. (DOI:https://doi.org/10.1016/j.jaap.2007.12.007).

80. R. Chand, K. Narimura, H. Kawakita, K. Ohto, T. Watari, K. Inoue, Grape Waste as a Biosorbent for Removing $\mathrm{Cr}$ (VI) from Aqueous Solution. Journal of Hazardous Materials, 2009, 163, 245-250. (DOI:https://doi.org/10.1016/j. jhazmat.2008.06.084).

81. M. Akram, H.N. Bhatti, M. Iqbal, S. Noreen, S. Sadaf. Biocomposite Efficiency for Cr(VI) Adsorption: Kinetic, Equilibrium and Thermodynamic Studies, Journal of Environmental and Chemical Engineering, 2017, 5, 400-411. (DOI:https://doi.org/10.1016/j.jece.2016.12.002).

82. W. Qi, Y. Zhao, X. Zheng, M. Ji, Z. Zhang, Adsorption Behavior and Mechanism of Cr (VI) Using Sakura Waste from Aqueous Solution, Applied Surface Science, 2016, 360, 470-476. (DOI:https://doi.org/10.1016/j.apsusc.2015.10.088)

83. E.Suganya, N. Saranya, S. Sivaprakasam, L.A. Varghese, S. Narayanasamy. Experimentation on Raw and Phosphoric Acid Activated Eucalyptuscamadulensis Seeds as Novel Biosorbents for Hexavalent Chromium Removal from Simulated and Electroplating Effluents, Environmental Technology and Innovation, 2020, 19, 100977.(DOI:https://doi. org/10.1016/j.eti.2020.100977).

84. K.M. Sreenivas, M.B. Inarkar, S.V. Gokhale, S.S. Lele. Re-utilization of Ash Gourd (Benincasahispida) Peel Waste for Chromium(VI) Biosorption: Equilibrium and Column Studies, Journal of Environmental Chemical Engineering, 2014, 2, 455-462.(DOI:https://doi.org/10.1016/j.jece.2014.01.017).

85. H. Chen, J. Dou, H. Xu, Removal of Cr(VI) Ions by Sewage Sludge Compost Biomass from Aqueous Solutions: Reduction to Cr(III) and Biosorption, Applied Surface Science, 2017, 425, 728-735. (DOI:https://doi.org/10.1016/j. apsusc.2017.07.053).

86. I. Enniya, L. Rghioui, A. Jourani, Adsorption of Hexavalent Chromium in Aqueous Solution on Activated Carbon Prepared from Apple Peels, Sustainable Chemistry and Pharmacy, 2018, 7, 9-16. (DOI:https://doi.org/10.1016/j. scp.2017.11.003).

87. F. Ghorbani, S. Kamari, S. Zamani, S. Akbari, M. Salehi, Optimization and Modeling of Aqueous Cr(VI) Adsorption onto Activated Carbon Prepared from Sugar Beet Bagasse Agricultural Waste by Application of Response Surface Methodology, Surfaces and Interfaces, 2020, 18, 100444. (DOI:https://doi.org/10.1016/j.surfin.2020.100444).

88. Tu, R. Wen, K. Wang, Y. Cheng, Y. Deng, W. Cao, K. Zhang, H.Tao. Efficient Removal of Aqueous Hexavalent Chromium by Activated Carbon Derived from Bermuda Grass, Journal of Colloid and Interface Science, 2020, 560, 649-658. (DOI:https://doi.org/10.1016/j.jcis.2019.10.103).

89. S. Sugashini, K.M.M.S. Begum, Preparation of Activated Carbon from Carbonized Rice Husk by Ozone Activation for Cr(VI) Removal, New Carbon Materials, 2015, 30, 252-261. (DOI:https://doi.org/10.1016/S1872-5805(15)60190-1).

90. J. Yang, M. Yu, W. Chen, Adsorption of Hexavalent Chromium from Aqueous Solution by Activated Carbon Prepared from Longan Seed: Kinetics, Equilibrium and Thermodynamics, Journal of Industrial and Engineering Chemistry, 2015, 21, 414-422. (DOI:https://doi.org/10.1016/j.jiec.2014.02.054).

91. V.E. Pakade, N.T. Tavengwa, L.M. Madikizela. Recent Advances in Hexavalent Chromium Removal From Aqueous Solutions by Adsorptive methods, RSC Advances, 2019, 9, 26142-26164.(DOI:https://oi.org/10.1039/C9RA05188K).

92. M.Y. Lee, K.J. Hong, Y. Shin-Ya, T. Kajiuchi. Adsorption of Hexavalent Chromium by Chitosan Based Polymeric Surfactants, Journal of Applied Polymer Science, 2005, 96, 44-50. (DOI:https://doi.org/10.1002/app.21356) 
93. R.A. Rao, F. Rehman. Adsorption Studies on Fruits of Gular (Ficusglomerata): Removal of Cr(VI) from Synthetic Wastewater, Journal of Hazardous Materials, 2010, 181, 405-412. (DOI:https://doi.org/10.1016/j.jhazmat.2010.05.025).

94. C.V. Gherasim, G. Bourceanu, R.I. Olariu, C. Arsene. A Novel Polymer Inclusion Membrane Applied in Chromium (VI) Separation from Aqueous Solutions, Journal of hazardous materials, 2011, 197, 244-253. (DOI: https://doi. org/10.1016/j.jhazmat.2011.09.082).

95. A. Fenti, S. Chianese, P. Iovino, D. Musmarra, S. Salvestrini. Cr(VI) Sorption from Aqueous Solution: A Review, Applied Sciences, 2020, 10, 6477. (DOI: https://doi.org/10.3390/app10186477).

96. J.W. Ball, D.K. Nordstrom. Critical Evaluation and Selection of Standard State Thermodynamic Properties for Chromium Metal and Its Aqueous Ions, Hydrolysis Species, Oxides, and Hydroxides, Journal of Chemical and Engineering Data, 1998, 43, 895-918. (DOI:https://doi.org/10.1021/je980080a).

97. B.R. James, R.J. Bartlett. Plant-Soil Interactions of Chromium, Journal of Environmental Quality, 1984, 13, 67-70. (DOI:https://doi.org/10.2134/jeq1984.00472425001300010012x).

98. R. Labied, O. Benturki, A.Y. EddineHamitouche, A. Donnot. Adsorption of Hexavalent Chromium by Activated Carbon Obtained from a Waste Lignocellulosic Material (ZiziphusJujuba Cores): Kinetic, Equilibrium, and Thermodynamic Study. Adsorption Science and Technology,2018, 36, 1066-1099.(DOI:https://doi.org/10.1177\%2F0263617417750739).

99. A.S. Santos, T.S. Santos, V.A. Lemos, A.O.D. Souza. Yellow Mombin (Spondiasmombin L.) Seeds from Agro-Industrial Waste as a Novel Adsorbent for Removal of Hexavalent Chromium from Aqueous Solutions, Journal of the Brazilian Chemical Society, 2021, 32, 437-446. (DOI:https://doi.org/10.21577/0103-5053.20200196). 